\author{
Monika Frąszczak
}

\title{
OKOLICZNOŚCI WYŁĄCZAJĄCE \\ ZAWARCIE MAEŻEŃSTWA \\ W KODEKSIE PRAWA KANONICZEGO Z 1983 ROKU
}

\begin{abstract}
WPROWADZENIE
Jednym $\mathrm{z}$ podstawowych praw człowieka jest prawo do swobodnego wyboru stanu życia, które wynika z kan. 219 obowiązującego Kodeksu Prawa Kanonicznego z 1983 r. ${ }^{1}$ Ustawodawca kościelny w kan. 1058 KPK/83 uszczegółowił to prawo, stanowiąc, że małżeństwo mogą zawrzeć osoby, którym prawo tego nie zabrania. W ten sposób zostało wyrażone ius connubii, czyli prawo do zawarcia małżeństwa. Jednakże prawo to w pewnych okolicznościach podlega ograniczeniom, które w prawie kanonicznym zostały określone mianem przeszkód małżeńskich. Dlatego też celem niniejszego artykułu będzie analiza poszczególnych przeszkód małżeńskich.
\end{abstract}

MGR LIC. Monika FrąSZCZAK - doktorant, Katedra Kościelnego Prawa Procesowego, Małżeńskiego i Karnego oraz Katolickich Kościołów Wschodnich, Wydział Prawa, Prawa Kanoniczego i Administracji, Katolicki Uniwersytetu Lubelskiego Jana Pawła II; adres do korespondencji: Al. Racławickie 14, 20-950 Lublin, Polska; e-mail: monika gorna94@gmail.com; https://orcid.org/0000-0002-8494-4417

${ }^{1}$ Codex Iuris Canonici auctoritate Ioannis Pauli PP. II promulgatus (25.01.1983), AAS 75 (1983), pars II, s. 1-317; tekst polski: Kodeks Prawa Kanonicznego, przekład polski zatwierdzony przez Konferencję Episkopatu, Pallottinum, Poznań 1984 [dalej: $\mathrm{KPK} / 83]$. 


\section{POJĘCIE I NATURA PRZESZKODY MAEŻEŃSKIEJ}

Przeszkody małżeńskie $\mathrm{w}$ prawie kanonicznym określa się mianem przeszkód zrywających, przez które należy rozumieć okoliczności dotyczące bezpośrednio osób, które są zakazami i wymagają wolności od nich przez osoby zawierające związek małżeński. Uzasadnienia ograniczeń wynikają z przesłanek wskazanych powyżej oraz z przesłanek natury religijnej [Góralski 2006, 21]. Przesłanki wyłączające możliwość zawarcia małżeństwa to inaczej ograniczenia dowolności w zawieraniu związków małżeńskich, przez które ustawodawca zacieśnił zakres swobody nupturientów ze względu na określone okoliczności dotyczące jednego z nich lub obojga. Źródłem takich ograniczeń mogą być przesłanki biologiczne, eugeniczne, racje natury moralnej lub sfera społeczno-obyczajowa [tamże, 27-28].

Kanoniczne przesłanki małżeńskie pochodzą z prawa Bożego naturalnego i pozytywnego, a także z prawa kościelnego. Przeszkodą z prawa Bożego naturalnego jest impotencja oraz pokrewieństwo w linii prostej oraz $\mathrm{w}$ drugim stopniu linii bocznej. Z prawa pozytywnego przeszkodą małżeńską będzie pozostawanie $\mathrm{w}$ związku małżeńskim. Jeżeli na małżeństwo spojrzymy z perspektywy aktu prawnego to, gdy chodzi o małżeństwo zawarte pomimo istnienia przeszkody z prawa Bożego, będzie ono skutkowało niezaistnieniem aktu prawnego. Natomiast w przypadku przeszkody z prawa kościelnego akt prawny będzie nieskuteczny [tamże, 31-32].

\section{PRZESZKODA WIEKU}

Zawarcie małżeństwa wymaga odpowiedniej zdolności psychicznej, jak i fizycznej, które osiąga się na pewnym stopniu dojrzałości, niezbędnej do przyjęcia świadomie i dobrowolnie nierozerwalnego węzła małżeńskiego. Zadaniem ustawodawcy jest ustalenie (w wymiarze przeciętności) odpowiednich danych dotyczących procesu rozwoju i dojrzewania człowieka, a następnie na ich podstawie określenie minimalnego wieku do zawarcia małżeństwa. Nieosiągnięcie przepisanego prawem wieku stanowi zatem przeszkodę do zawarcia małżeństwa [Góralski 2011b, 108]. Prawodawca kościelny w kan. $1083 \S 1 \mathrm{KPK} / 83$ stanowi, że nie może zawrzeć ważnego małżeństwa mężczyzna przed ukończeniem szesnastego roku życia i kobieta przed ukończeniem czternastego roku. Wiek nupturienta ustala się na podstawie 
danych zaczerpniętych z ksiąg parafialnych lub innych dokumentów publicznych (w tym cywilnych) albo na podstawie zeznania rodziców zainteresowanego bądź innych osób znających datę urodzin [tamże, 109].

Przeszkoda wieku wynika $\mathrm{z}$ faktu, że jeden lub oboje nupturienci nie osiągnęli wymaganego prawem wieku. Do podjęcia zobowiązań, jakie wypływają z aktu zawarcia małżeństwa, wymagana jest pewna dojrzałość. Prawodawca kościelny stanowi domniemanie prawne, że podmiot wraz z osiągnięciem pewnego wieku osiągnął naturalną zdolność do zawarcia małżeństwa. Ustawodawca określając granicę wieku wychodzi z założenia, że osoba, która osiągnęła wymagany przez prawo wiek, wraz z nim osiągnęła odpowiedni rozwój biologiczny, a także odpowiednią dojrzałość do zawarcia małżeństwa [Kamiński 2017, 45].

Wiek określony przez prawodawcę jest wiekiem minimalnym, a do tego bardzo niskim. Na mocy kan. 1083 § 2 KPK/83 poszczególne konferencje biskupów mogą podwyższać tę granicę, dostosowując ją do prawodawstwa świeckiego oraz warunków kulturowych, w których żyją poszczególni wierni. Należy jednak zwrócić uwagę, że prawo kanoniczne nie udziela dyspensy mężczyźnie, który nie ukończył 18 roku życia [tamże, 45-46]. Konferencja Episkopatu Polski w Instrukcji dla duszpasterzy dotyczqcej małżeństwa konkordatowego ${ }^{2}$ z dnia 22 października 1998 r. dostosowała prawo kościelne do prawa świeckiego, zrównując wiek do lat 18 dla kobiety i mężczyzny, niezależnie od tego, jakie małżeństwo zawierają.

Przeszkoda wieku ma charakter absolutny i czasowy, co oznacza, że ustaje wraz z osiągnięciem przez nupturienta wymaganego wieku, ale uprzednio zawarte przez niego małżeństwo nie staje się ważne na mocy samego prawa [Dzierżon 2016, 87; Kamiński 2017, 46]. W celu dokonania konwalidacji takiego związku należy ponownie wyrazić zgodę małżeńską albo prosić Kongregację ds. Kultu Bożego i Dyscypliny Sakramentów lub biskupa diecezjalnego o łaskę uzdrowienia w zawiązku [Krajczyński 2012, 66].

Podstawą takiej regulacji prawnej jest m.in. troska, aby młodzi nupturienci nie zawierali małżeństwa lekkomyślnie, bez uprzedniej dojrzałości umysłowej i przygotowania do samodzielnego życia. Małżeństwa zawierane przez osoby nieletnie są szczególnie podatne na rozbicie [Pawluk 1984, 126]. Kanoniści wskazują, że podstawą usankcjonowania małżeńskiej

\footnotetext{
${ }^{2}$ Konferencja Episkopatu Polski, Instrukcja dla księży dotyczqca matżeństwa konkordatowego (22.10.1998), „Biuletyn Katolickiej Agencji Prasowej” z 13.11.1998, nr 46, s. 15-17.
} 
przeszkody wieku są przyczyny natury moralnej i społecznej, a także motywy medyczne i fizjologiczne [Krajczyński 2012, 62-63]. Nadanie okoliczności wieku nupturienta charakteru absolutnego, zróżnicowanie wieku kanonicznego mężczyzny i kobiety oraz uwzględnienie przez prawodawcę faktu, że ustanowiony w kan. $1083 \S 1 \mathrm{KPK} / 83$ wiek jest wiekiem średnim dla ludzi mieszkających na całym świecie, a tym samym nie może odpowiadać faktycznym warunkom dojrzewania fizycznego we wszystkich krajach. Dlatego też prawodawca upoważnia ordynariuszy miejsca do dyspensowania od przeszkody wieku, nawet gdy brak wieku przekracza jeden rok, co oznacza poszanowanie zasad godności osoby ludzkiej. Takie rozwiązania respektują odrębne warunki rozwoju ludzi w różnych rejonach świata oraz zabezpieczają skutecznie dobro całej wspólnoty [tamże, 64].

\section{PRZESZKODA IMPOTENCJI}

Prawodawca kościelny w kan. 1084 KPK/83 ustanowił drugą przeszkodę do zawarcia małżeństwa, czyli przesłankę niemocy płciowej. Przeszkoda niemocy płciowej, inaczej impotencji, jak uważa W. Góralski, jest niezdolnością do spełnienia przez stronę aktu małżeńskiego rozumianego jako erectio et penetratio virilis in vagina mulieris et eiaculatio seminis. Niezdolność ta zarówno absolutna, jak i relatywna musi odznaczać się cechami uprzedniości i trwałości. Przeszkoda ta wynika z prawa naturalnego, od której nie można dyspensować. Uprzedniość przeszkody oznacza, że przeszkoda powinna istnieć przed zawarciem małżeństwa lub najpóźniej w momencie jego zawierania. Natomiast trwałość niemocy płciowej polega na tym, że jest ona nieuleczalna przy zastosowaniu środków zwyczajnych. Konieczność użycia środków nadzwyczajnych do usunięcia impotencji, np. ryzykownej dla życia lub zdrowia albo bardzo kosztownej operacji, pozwala przyjąć, że jest ona trwała. Cecha absolutności impotencji uniezdalnia do współżycia cielesnego z każdą osobą odmiennej płci, zaś cecha relatywności uniezdalnia do współżycia z osobą, z którą nupturient zawiera małżeństwo. Wskazane w przepisie kanonu cechy impotencji przesądzają o istnieniu przeszkody niezależnie od jej przyczyn (organicznych, np. wadliwej budowy narządów, czy też funkcjonalnych, jak np. zaburzenia stanu psychicznego). W przypadku wątpliwości - zarówno prawnej, jak i faktycznej - co do istnienia przeszkody nie należy zabraniać zawarcia małżeństwa. 
Zgodnie z kan. $1058 \mathrm{KPK} / 83$ każdy ma prawo do zawarcia małżeństwa, chyba że prawo mu tego zabrania. Zakaz prawa dotyczy jedynie przypadków przeszkód pewnych, a nie wątpliwych. Jednakże w przypadku istnienia wspomnianej wątpliwości trybunał kościelny nie może orzekać nieważności małżeństwa z tytułu tejże przeszkody (kan. 1084 § $2 \mathrm{KPK} / 83$ ) [Góralski 2011b, 283-84].

Niezdolność, o której stanowi prawodawca kościelny polega na tym, że przynajmniej jedna ze stron jest niezdolna do współżycia małżeńskiego. Nie chodzi zatem o niezdolność do zrodzenia potomstwa. Zdolność do współżycia małżeńskiego zakłada możliwość erekcji, penetracji i ejakulacji w pochwie kobiety (ze strony mężczyzny) oraz przyjęcia ejakulatu w pochwie (ze strony kobiety) [Tenże 2011a, 113]. Należy przy tym zauważyć, że prawodawstwo kościelne nie zabrania zawarcia małżeństwa $\mathrm{z}$ powodu niepłodności, a sama niepłodność nie powoduje nieważności małżeństwa [tamże, 116].

\section{PRZESZKODA WĘZŁA MAŁŻEŃSKIEGO}

Ustawodawca w kan. $1085 \S 1 \mathrm{KPK} / 83$ stanowi, że „nieważnie usiłuje zawrzeć małżeństwo, kto jest związany węzłem poprzedniego małżeństwa, nawet niedopełnionego". W tej sytuacji przeszkodę małżeńską stanowi istniejący węzeł małżeński, a zatem ten, kto jest związany już węzłem małżeńskim, nieważnie usiłuje zawrzeć kolejne małżeństwo. W danym przypadku może występować chęć nadania zewnętrznych pozorów zawarcia małżeństwa, które by uchodziło za ważne w opinii środowiska. Nie wpłynie to jednak nigdy na ważność danego związku. Ponadto nieważnie będzie zawarta, nawet w dobrej wierze, umowa małżeńska oparta na tzw. dekrecie wdowieństwa (domniemanej śmierci poprzedniego małżonka wystawionym przez władzę kościelną, jeśli się okaże, że obiektywnie jest on nieprawdziwy, ponieważ ów małżonek de facto żyje). Przywołany kanon chroni również istniejący węzeł małżeński oraz prawa drugiego współmałżonka, jak również chroni społeczność przed bigamią [Góralski 2011a, 117-18]. W drugiej części tegoż kanonu prawodawca stanowi, że nawet gdyby pierwsze małżeństwo zostało nieważnie zawarte, to dopóki zgodnie z prawem i w sposób pewny nie stwierdzi się jego nieważności, nie można zawrzeć ponownego małżeństwa (kan. 1085 § 2 KPK/83). 
Przeszkoda węzła małżeńskiego pochodzi z prawa Bożego naturalnego i pozytywnego, dlatego też niemożliwa jest od niej dyspensa. Przeszkoda ta ustaje na skutek ustania węzła małżeńskiego, tzn. gdy jeden ze współmałżonków umrze, zostanie stwierdzona nieważność małżeństwa prawomocnym orzeczeniem sądu kościelnego lub zostanie udzielona dyspensa papieska od małżeństwa zawartego i niedopełnionego albo na mocy przywileju Pawłowego [tamże, 118].

\section{PRZESZKODA RÓŻNEJ RELIGII}

Przeszkoda różnej religii, o której stanowi prawodawca w kan. 1086 KPK/83, powstaje w momencie, gdy katolik próbuje ważnie zawrzeć małżeństwo z osobą nieochrzczoną. W 2009 r. papież Benedykt XVI na mocy motu proprio Omnium in mentem ${ }^{3}$ dokonał zmiany przywołanego przepisu, usuwając z niego sformułowanie „i nie odłączyła się od niego formalnym aktem". W obowiązującym stanie prawnym przez stronę katolicką rozumie się tego, kto został w Kościele katolickim ochrzczony lub został do niego po chrzcie formalnie przyjęty. Natomiast osoba nieochrzczona to taka, która albo chrztu nie otrzymała albo otrzymała go nieważnie. Przeszkoda różności religii powstaje zatem, gdy katolik próbuje zawrzeć małżeństwo właśnie z taką osobą [Kamiński 2017, 52-53].

Omawiana przeszkoda pochodzi z prawa kościelnego, dlatego możliwe jest uzyskanie od niej dyspensy. Uzyskanie dyspensy możliwe jest po spełnieniu warunków określonych w kan. 1125 i 1126 KPK/83, tj. słuszna i racjonalna przyczyna, zobowiązanie strony katolickiej odsunięcia od siebie niebezpieczeństwa utraty wiary oraz ochrzczenia i wychowania potomstwa w wierze Kościoła katolickiego oraz przyjęcia do wiadomości tego zobowiązania przez stronę nieochrzczoną. Ponadto prawodawca stawia wymóg, aby obie strony zostały pouczone o istotnych przymiotach i celach małżeństwa. Jeśli któraś ze stron pozytywnym aktem woli wykluczy jakiś przymiot lub cel małżeństwa, wówczas zawarty związek małżeński będzie skutkował jego nieważnością zgodnie z kan. 1101 § 2 KPK/83 [tamże, 53-54].

\footnotetext{
${ }^{3}$ Benedictus PP. XVI, Motu proprio Omnium in mentem (26.10.2009), AAS 102 (2010), s. 8-10.
} 


\section{PRZESZKODA ŚWIĘCEŃ}

Prawodawca w kan. $1087 \mathrm{KPK} / 83$ stanowi, że nieważnie usiłują zawrzeć małżeństwo ci, którzy otrzymali święcenia. Przeszkodą tą objęci są ci, którzy przyjęli święcenia diakonatu, prezbiteratu oraz biskupie. Poza tym przeszkodą objęty jest również diakon stały żonaty, a zatem po śmierci żony nie może ważnie zawrzeć następnego małżeństwa. Z chwilą przyjęcia święceń diakonatu diakon zobowiązuje się do zachowania celibatu. Należy zwrócić uwagę, że przeszkodę stanowią święcenia przyjęte ważnie, a ewentualną nieważność święceń należy udowodnić na drodze sądowej [Góralski 2011b, 287].

Przeszkoda ta pochodzi z prawa kościelnego, natomiast udzielenie od niej dyspensy zastrzeżone jest Stolicy Apostolskiej. Natomiast w przypadku dyspensy od obowiązku celibatu należy zwrócić się do Kongregacji Nauki Wiary, jeśli zachodzi jedna z okoliczności: 1) brak należytej wolności w przyjmowaniu święceń; 2) brak należytej odpowiedzialności w przyjmowaniu święceń; 3) brak u przełożonych kwalifikujących się do święceń roztropnego, wystarczającego i miarodajnego sądu w danej ocenie kandydata do stałego życia w celibacie [tamże].

\section{PRZESZKODA PUBLICZNEGO ŚLUBU CZYSTOŚCI}

Kolejna przeszkoda do zawarcia małżeństwa została uregulowana w kan. $1088 \mathrm{KPK} / 83$ i dotyczy wieczystego publicznego ślubu czystości złożonego w instytucie zakonnym. Przeszkoda ta odnosi się do wszystkich ślubów publicznych wieczystych składanych w instytutach zakonnych, a nie - jak miało to miejsce w poprzednim prawodawstwie - tylko do ślubów uroczystych, zaś śluby proste były traktowane jako przeszkoda wzbraniająca. Źródłem przeszkody jest publiczny ślub czystości złożony w instytucie zakonnym. Ślub publiczny to taki, który został przyjęty w imieniu Kościoła przez właściwego przełożonego i złożony w instytucie zakonnym w rozumieniu kan. $607 \S 2$, zgodnie z obrzędem profesji zakonnej. Aby publiczny ślub czystości mógł stanowić przeszkodę musi być jednocześnie wieczysty, a więc złożony po upływie ślubów czasowych, zgodnie z przepisami zakonnymi. Natomiast ślub czystości prywatny oraz złożony w instytucie zakonnym świeckim nie stanowi przeszkody rozrywającej. Ślub ten 
musi nadto być ważnie złożony i istnieć w chwili zawierania małżeństwa [Gręźlikowski 2012, 84-85].

Powyższa przeszkoda pochodzi z prawa kościelnego, dlatego też może ustać na skutek indultu sekularyzacyjnego, wydalenia z zakonu lub przez dyspensę. Jeżeli indult sekularyzacyjny został prawnie udzielony i przyjęty przez osobę odchodzącą $\mathrm{z}$ instytutu zakonnego, to zawiera on również dyspensę od wszystkich złożonych ślubów i obowiązków wynikających z profesji zakonnej. Wszystkie śluby zakonne ustają, gdy członek instytutu zakonnego otrzyma dekret dymisyjny usuwający go ze społeczności zakonnej. Natomiast bezpośrednia dyspensa od przeszkody ślubu zastrzeżona jest Stolicy Apostolskiej [tamże, 85].

\section{PRZESZKODA UPROWADZENIA}

Przeszkoda uprowadzenia została uregulowana w kan. 1089 KPK/83, w którym prawodawca stanowi, że nie może być ważnie zawarte małżeństwo pomiędzy mężczyzną i kobietą uprowadzoną lub choćby przetrzymywaną z zamiarem zawarcia $\mathrm{z}$ nią małżeństwa, chyba że później kobieta uwolniona od porywacza oraz znajdując się w miejscu bezpiecznym i wolnym, sama swobodnie wybierze to małżeństwo. Ustanowienie takiej przesłanki wynika z faktu, że nadal zdarzają się przypadki, kiedy to uprowadzone kobiety wyrażają zgodę małżeńską wbrew swojej woli, ponieważ pozostają $\mathrm{w}$ stanie zależności od dopuszczających się uprowadzenia lub zatrzymania mężczyzn [Krajczyński 2012, 66]. Uprowadzenie kobiety do innego miejsca niż jej własne miejsce pobytu albo też przetrzymywanie w jej własnym miejscu pobytu lub miejscu, do którego dobrowolnie przybyła, nie musi dokonać się z użyciem przemocy fizycznej. Mężczyzna, który dokonał uprowadzenia bądź też zatrzymania kobiety, osobiście lub przez inną osobę, staje się niezdolny do zawarcia ważnego małżeństwa z tą kobietą. Przeszkoda ta dotyczy również wypadku, gdy uprowadzenie lub zatrzymanie kobiety dokonało się z wykorzystaniem przemocy moralnej, jak np. groźba, szantaż, podstęp. Inną okolicznością zaistnienia analizowanej przeszkody jest przypadek użycia przemocy, która nie wywołała u kobiety bojaźni, albo gdy kobieta zgodziła się na zawarcie małżeństwa, ale sprzeciwiała się uprowadzeniu i zatrzymaniu. Przeszkodę stanowi jedynie uprowadzenie lub zatrzymanie, podjęte $\mathrm{w}$ celu zawarcia małżeństwa 
z uprowadzoną lub zatrzymaną. Przeszkoda natomiast nie zachodzi w sytuacji uprowadzenia czy też zatrzymania dokonanego dla innych celów (np. wymuszenia okupu). Podobnie jak w przypadku uprowadzenia lub zatrzymania dokonanego za zgodą kobiety albo jeśli osoba, która uprowadzi lub zatrzyma kobietę dla jakiegoś mężczyzny bez jego zlecenia, przeszkoda nie powstanie. Przeszkoda uprowadzenia istnieje do momentu, gdy kobieta uprowadzona lub zatrzymana siłą nie jest odseparowana od porywacza i nie znajduje się w miejscu bezpiecznym i wolnym. Określenia „bezpieczny” i „wolny” odnoszą się natomiast do miejsca pobytu, a nie do kobiety i jej stanu wewnętrznego. Dyspensy od przeszkody uprowadzenia można udzielić tylko wtedy, gdy ma się pewność moralną co do swobodnej i niezależnej decyzji kobiety uprowadzonej lub zatrzymanej [tamże, 67-68].

\section{PRZESZKODA WYSTĘPKU}

Następna przeszkoda małżeńska została uregulowana w kan. 1090 KPK/83 i odnosi się do przeszkody występku. Zakres tejże przeszkody odnosi się wyłącznie do zabójstwa małżonka. Źródłem przeszkody są pewne kwalifikowane czyny skierowane wprost przeciw bezpieczeństwu i życiu jednego z małżonków, takie jak: małżonkobójstwo w sensie właściwym tzn. spowodowanie śmierci własnego małżonka; małżonkobójstwo w znaczeniu niewłaściwym, tj. zabójstwo małżonka tej osoby, z którą pragnie zawrzeć się małżeństwo; małżonkobójstwo dokonane przez obie strony poprzez działanie fizyczne lub moralne. Należy pamiętać, że w dwóch pierwszych przypadkach czyn ten musi być dokonany z zamiarem zawarcia małżeństwa, natomiast gdy chodzi o współudział stron w zabójstwie, to niekoniecznie musi być on zrealizowany $\mathrm{z}$ zamiarem zawarcia małżeństwa [tamże, 70].

W przypadku ustalania, czy współudział fizyczny lub moralny stron miał miejsce, należy zauważyć, że współudział fizyczny zakłada fizyczne działania tychże osób zmierzające do dokonania przestępstwa, natomiast współsprawstwo moralne niekoniecznie musi oznaczać współsprawstwo konieczne, czyli takie, bez którego przestępstwo nie byłoby dokonane. W tym wypadku wystarczy tylko polecenie, podżeganie, szantaż, zachęta, nakłanianie, pomoc w doborze środków zabójstwa. Natomiast współudział moralny należy odróżnić od tzw. pomocnictwa, które może na przykład 
polegać na ułatwieniu dokonania zbrodni, zaniedbaniu obowiązku niedopuszczenia do niej, jej pochwale lub aprobacie. Dyspensa od przeszkody występku zastrzeżona jest Stolicy Apostolskiej [tamże, 70-71].

\section{PRZESZKODA POKREWIEŃSTWA I POWINOWACTWA}

Przeszkoda pokrewieństwa została ujęta w kan. 1091 KPK/83, zaś przeszkoda powinowactwa w kan. $1092 \mathrm{KPK} / 83$. Obydwie przeszkody pozostają ze sobą w pewnym związku, ponieważ zgodnie z kan. $109 \mathrm{KPK} / 83$ powinowactwo określane jest jako węzeł powstający $\mathrm{z}$ ważnie zawartego małżeństwa (nawet niedopełnionego) wiążący małżonka z krewnymi współmałżonka. Podstawą ograniczenia jest małżeństwo ważne, sakramentalne oraz niesakramentalne, nie ma natomiast znaczenia fakt dopełnienia małżeństwa (kan. $109 \mathrm{KPK} / 83$ ).

Pokrewieństwo naturalne powstaje poprzez więzy krwi, a więc przez zrodzenie bezpośrednie lub pośrednie od wspólnego przodka. Przez pojęcie wspólnego przodka należy rozumieć parę osób lub jedną osobę, od której pochodzą krewni. Ponadto pokrewieństwo może być bliższe lub dalsze. W systemach prawnych relacje te określa się poprzez linie i stopnie pokrewieństwa. Linia prosta oznacza, że kolejne osoby pochodzą bezpośrednio jedna od drugiej, zaś w linii bocznej jeśli do wspólnego przodka pochodzi równolegle więcej osób, przy czym może to być pokrewieństwo w linii bocznej równej (gdy osoby pochodzą od jednego przodka w identycznym stopniu) bądź też w linii bocznej nierównej (gdy osoby są oddalone od jednego przodka w nieidentycznym stopniu) [Kamiński 2017, 60-61].

Przeszkoda w linii prostej sięga w nieskończoność. Natomiast w linii bocznej przeszkoda obejmuje czwarty stopień linii bocznej. Z prawa naturalnego pochodzi przeszkoda pokrewieństwa w linii prostej i $\mathrm{w}$ drugim stopniu linii bocznej, dlatego dyspensa nie jest możliwa. Jeśli zaś chodzi o pokrewieństwo $\mathrm{w}$ trzecim i w czwartym stopniu linii bocznej, to jest to przeszkoda z prawa pozytywnego i możliwe jest uzyskanie dyspensy [tamże, 61-62]. W przypadku przeszkody powinowactwa, to w linii prostej we wszystkich stopniach powoduje ona nieważność małżeństwa (kan. 1092 KPK/83). Oznacza to, że małżeństwa nie może zawrzeć wdowiec z wstępnymi i zstępnymi zmarłej żony, a także wdowa z wstępnymi i zstępnymi 
zmarłego męża [tamże, 62]. Przeszkoda ta pochodzi z prawa kościelnego, dlatego można uzyskać od niej dyspensę [Góralski 2011b, 292].

\section{PRZESZKODA PRZYZWOITOŚCI PUBLICZNEJ}

Podstawą przeszkody przyzwoitości publicznej, o której stanowi prawodawca w kan. $1093 \mathrm{KPK} / 83$ jest nieważne małżeństwo (nieważność musi zostać stwierdzona przez sąd kościelny) po rozpoczęciu życia wspólnego albo notoryczny lub publiczny konkubinat. Konkubinat polega na trwałym niezalegalizowanym pożyciu na sposób małżeński przez osoby niezwiązane związkiem małżeńskim. Konkubinat jest notoryczny, jeśli jest znany publicznie i nie da się go ukryć, albo został stwierdzony sądownie. Przez publiczny konkubinat należy rozumieć to, iż jest on znany szerszemu kręgowi osób lub jest prawdopodobne, że wkrótce będzie faktem powszechnie znanym. Jednakże małżeństwo cywilne nie jest źródłem przeszkody. Zakres przeszkody obejmuje wyłącznie pierwszy stopień linii prostej. $\mathrm{Na}$ przykład mężczyzna po ustaniu wspólnoty życia, związany jest przeszkodą z matką oraz z córką kobiety, z którą pozostawał w nieważnym małżeństwie albo notorycznym lub publicznym konkubinacie. Przeszkoda przyzwoitości publicznej ma na celu, aby osoby, które pozostawały ze sobą $\mathrm{w}$ tak bliskiej więzi nie wiązały się $\mathrm{z}$ najbliższymi krewnymi drugiej strony. Przeszkoda ta pochodzi z prawa kościelnego w związku z tym można od niej dyspensować. Przeszkoda nie ustaje na skutek zerwania pożycia przez strony stwierdzone nieważnością małżeństwa przez sąd kościelny albo też ustania konkubinatu [Góralski 2011b, 292-93].

\section{PRZESZKODA POKREWIEŃSTWA PRAWNEGO}

Przeszkoda pokrewieństwa prawnego zawarta w kan. 1094 KPK/83 powstaje na skutek adopcji, tj. prawnego przysposobienia. Podstawę przeszkody stanowi wyłącznie stosunek adopcji prawnej powstały na mocy prawa państwowego. W linii prostej przeszkoda zachodzi między: 1) adoptującym i adoptowanym; 2) adoptowanym i krewnymi wstępnymi adoptującego; 3) adoptującym i krewnymi zstępnymi adoptowanego. Natomiast w linii bocznej przeszkoda zachodzi między adoptowanym i dziećmi naturalnymi 
adoptującego. Przeszkoda pochodzi z prawa kościelnego i możliwa jest od niej dyspensa. Przeszkoda ustaje również przez rozwiązanie stosunku adopcyjnego [Góralski 2011a, 138-40].

\section{ZAKOŃCZENIE}

Kanoniczne przeszkody małżeńskie odgrywają dużą rolę w prawodawstwie kościelnym, bowiem ich istnienie wpływa na wykonywanie ius connubii, jak również służą ochronie istotnych wartości instytucji małżeństwa, dobru małżonków oraz dobru społeczności kościelnej. Obecne prawodawstwo kościelne, w stosunku do wcześniejszego prawodawstwa zredukowało liczbę przeszkód do dwunastu i jednocześnie odstąpiło od podziału na przeszkody zrywające i wzbraniające na rzecz przeszkód rozrywających. Przeszkody małżeńskie dotyczą nie tylko zakazu zawarcia małżeństwa, ale również odnoszą się do zakazu zawierania związku małżeńskiego pod sankcją nieważności. Tym samym należą do rodzaju praw uniezdalniających, przez co osoba staje się niezdolna do określonego działania prawnego.

Okoliczności wyłączające zawarcie małżeństwa w ujęciu kodeksowym dzielą się na te o charakterze publicznym i tajnym, których istnienie zależy od tego, czy daną przeszkodę można udowodnić na forum zewnętrznym. Natomiast w doktrynie kanonicznej przeszkody dzieli się według różnych kryteriów, tj. ze względu na źródło pochodzenia, na zakres, czas trwania, czas powstania, stopień pewności oraz możliwość dyspensowania. Przeszkody, które wyróżniamy ze względu na źródło pochodzenia dzielą się na te, których źródłem jest prawo Boże naturalne lub pozytywne albo prawo kościelne. Okolicznościami wyłączającymi zawarcie małżeństwa ze względu na przeszkodę z prawa Bożego są impotencja, węzeł małżeński oraz pokrewieństwo w linii prostej oraz w drugim stopniu linii bocznej, od których nie ma możliwości uzyskania dyspensy. Pozostałe przeszkody, o których stanowi KPK/83 pochodzą z ustanowienia Kościoła i można od nich dyspensować. Drugim kryterium podziału jest kryterium zakresu przeszkody. I tak wyróżnia się przeszkody bezwzględne, określane również jako absolutne oraz przeszkody względne, czyli relatywne. Skutkiem przeszkody bezwzględnej jest brak możliwości zawarcia małżeństwa przez osobę dotkniętą taką przeszkodą, np. w przypadku przeszkody wieku lub węzła 
małżeńskiego. Przeszkoda względna powoduje zaś niezdolność do zawarcia małżeństwa tylko z pewną kategorią osób, np. przeszkoda pokrewieństwa czy też powinowactwa. Trzecim kryterium podziału okoliczności wyłączających zawarcie małżeństwa jest czas trwania przeszkody. Tutaj wyróżnia się przeszkody stałe, które nigdy nie ustają, np. przeszkoda pokrewieństwa oraz przeszkody czasowe, które ustają z upływem czasu, np. przeszkoda wieku. Kolejnym kryterium podziału będzie czas powstania przeszkody. W tej sytuacji mamy przeszkody uprzednie, to znaczy, że przeszkoda istniała już przed zawarciem małżeństwa oraz przeszkody następcze powstałe po zawarciu związku małżeńskiego. Jednakże wpływ na ważność zawartego małżeństwa mają tylko przeszkody uprzednie. Innym kryterium podziału jest stopień pewności istnienia przeszkody, który należy ustalić. Przeszkody, co do których istnienia nie ma żadnych wątpliwości określa się jako pewne, natomiast przeszkody, których istnienia pewności nie ma, nazywa się wątpliwymi. Ostatnim kryterium podziału przeszkód jest kryterium dyspensowania. W związku z tym kryterium wyróżnia się trzy grupy przeszkód, mianowicie te, od których dyspensa jest możliwa, przeszkody, od których nie ma możliwości uzyskania dyspensy, a także przeszkody, od których można dyspensować, ale nie zwykło się tego czynić. Chodzi tutaj o przeszkodę występku, czyli małżonkobójstwa.

\section{PIŚMIENNICTWO}

Dzierżon, Ginter. 2016. „Przeszkoda wieku.” W Przeszkody matżeńskie $w$ prawie kanonicznym, red. Wojciech Góralski, 67-90, Warszawa: Wydawnictwo UKSW.

Góralski, Wojciech. 2006. „Przesłanki zawarcia małżeństwa w prawie polskim i w prawie kanonicznym." Ius Matrimoniale 11 (17):19-51.

Góralski, Wojciech. 2011a. Małżeństwo kanoniczne. Warszawa: LexisNexis.

Góralski, Wojciech. 2011b. „Tytuł VII. Małżeństwo.” W Komentarz do Kodeksu Prawa Kanonicznego. T. III/2: Księga IV. Uświęcające zadanie Kościoła, red. Józef Krukowski, 250-310. Poznań: Pallottinum.

Gręźlikowski, Janusz. 2012. „Przeszkody małżeńskie wynikające z węzła religijnego.” Prawo Kanoniczne 55, nr 3:73-93.

Kamiński, Rafał. 2017. „Przeszkody małżeńskie w prawie kanonicznym.” W Kanoniczne prawo matżeńskie - wybrane zagadnienia, red. Anna Chciałowska, Kaja Niewiadomska, i Marta Olkowicz, 33-70. Warszawa-Kraków: Wydawnictwo „Scriptum”.

Krajczyński, Jan. 2012. „Przeszkody małżeńskie wynikające z godności osoby.” Prawo Kanoniczne $55 \mathrm{nr}$ 3:53-72. 
Pawluk, Tadeusz. 1984. Prawo kanoniczne wedtug Kodeksu Jana Pawła II. T. 3: Prawo matżeńskie. Olsztyn: Warmińskie Wydawnictwo Diecezjalne.

\title{
Okoliczności wyłączające zawarcie małżeństwa w Kodeksie Prawa Kanoniczego z 1983 roku
}

\begin{abstract}
Abstrakt
W Kodeksie Prawa Kanonicznego z 1983 r. zostały ustanowione okoliczności wyłączające zawarcie małżeństwa, określane również jako przeszkody małżeńskie. Istnienie przeszkód małżeńskich ma na celu prawną ochronę instytucji małżeństwa, nie zaś ograniczenie prawa do zawarcia małżeństwa. Katalog tychże okoliczności obejmuje 12 przeszkód małżeńskich: przeszkodę wieku, impotencji, węzła małżeńskiego, różnej religii, święceń, wieczystego publicznego ślubu czystości złożonego w instytucie zakonnym, uprowadzenia, występku, pokrewieństwa, powinowactwa, przyzwoitości publicznej oraz pokrewieństwa prawnego. Przeszkody te rozróżnia się ze względu na źródło pochodzenia, zakres, czas trwania, czas powstania, stopień pewności oraz możliwość dyspensowania. W niniejszym artykule zaprezentowano nie tylko poszczególne przeszkody, ale również zdefiniowano pojęcie przeszkody oraz ich typologię.
\end{abstract}

Słowa kluczowe: przeszkody małżeńskie; zawarcie małżeństwa; prawo małżeńskie; prawo kanoniczne; małżeństwo kanoniczne

\section{Circumstances Excluding the Conclusion of Marriage in the 1983 Code of Canon Law}

\begin{abstract}
The 1983 Code of Canon Law establishes circumstances that preclude marriage, also referred to as marital impediments. The existence of marital impediments is intended to legally protect the institution of marriage, not to limit the right to marry. The catalog of these circumstances includes 12 marriage impediments: the impediment of age, impotence, the marriage tie, difference of religions, holy orders, public eternal vow of purity, abduction, spousal suicide, consanguinity, affinity, public decency, and legal kinship. These impediments are distinguished by their source, scope, duration, time of origin, degree of certainty, and dispensability. This article presents not only the individual impediments, but also defines the concept of impediment and their typology.
\end{abstract}

Keywords: marriage impediments; marriage contract; matrimonial law; canon law; canonical marriage

Information about Author: MonIKA FrĄSZCZAK, J.C.L. - Ph.D. student, Department of Church Procedural Law, Marriage Law and Penal Law and the Eastern Catholic Churches, Faculty od Law, Canon Law and Administration, The John Paul II Catholic University of Lublin; correspondence address: Al. Racławickie 14, 20-950 Lublin, Poland; e-mail: monikagorna94@gmail.com; https://orcid.org/0000-0002-8494-4417 